\title{
EL ALMA TIRÁNICA DE ALCIBÍADES EN EL BANQUETE DE PLATÓN
}

\author{
Esteban BIEDA \\ Universidad de Buenos Aires \\ CONICET
}

\section{Resumen}

Los hechos dramáticos narrados en el Banquete de Platón tienen lugar en el año 416 a.C. (triunfo de Agatón en las Leneas). Situado en el año siguiente, 415 a.C., Tucídides destaca un aspecto puntual de la personalidad del Alcibíades histórico: sus supuestas aspiraciones tiránicas. ¿Existe alguna manera de vincular al amante enloquecido del Banquete con el proto-tirano de Tucídides? En el presente trabajo proponemos que la clave para explicar la complejidad del personaje de Alcibíades en Banquete radica en la descripción del alma del hombre-tiránico de República VIII-IX. Para ello, en primer lugar haremos una semblanza del célebre general ateniense según los testimonios de Tucídides y Plutarco; en segundo lugar, expondremos las características del alma tiránica tal como es descrita en República; finalmente, integraremos todos estos elementos a fin de interpretar las palabras de Alcibíades en el Banquete, intentando mostrar cómo Platón deja entrever allí, sutilmente, las características tiránicas o proto-tiránicas de su alma.

Palabras clave: Alcibíades, Platón, Banquete, República, Tucídides.

\section{Abstract}

The reunion described in Plato's Symposium takes place in the year 416 b.C.. One year later, Thucydides points out one specific aspect of the personality of the historical Alcibiades: his alleged tyrannical aspirations. Is there any way in which it would be possible to link the berserk lover of the Symposium with the proto-tyrant of Thucydides? In this article I propose that the key to explain the complexity of Plato's character lies in the description of the soul of the tyrannical man in Republic VIII-IX. In order to do that, first I will do a portrayal of the famous Athenian general according to Thucydides and Plutarch; secondly, I will

Recibido: 14/02/2015. Aceptado: 09/06/2015. 
expound the characteristics of the tyrannical soul as it is described in the Republic; finally, I will integrate all these elements in order to interpret Alcibiades words in the Symposium, trying to show how Plato suggests some tyrannical aspects of his soul.

Keywords: Alcibiades, Plato, Symposium, Republic, Thucydides.

La inteligencia y habilidad que ponía en tales asuntos y discursos políticos contrastaban con la lascivia de su modo de vida, sus excesos de bebida y amores, la afeminación de los vestidos púrpuras que arrastraba por el ágora, su extravagancia arrogante [...] y la fabricación de un escudo dorado sin ninguna insignia patria, sino con un Eros con cuernos ${ }^{1}$.

Plutarco, Alcibiades 16.1-2

Los hechos dramáticos narrados en el Banquete de Platón tienen lugar en el año 416 a.C. (triunfo de Agatón en las Leneas). Situado en el año siguiente, 415 a.C., Tucídides destaca un aspecto puntual de la personalidad del Alcibíades histórico: sus supuestas aspiraciones tiránicas. Las causas de esta sospecha giran en torno a sus conductas privadas, especialmente a propósito de su afición por la satisfacción de placeres corporales por fuera de toda norma. ¿Existe alguna manera de vincular al amante enloquecido del Banq. con el proto-tirano de Tucídides? En el presente trabajo proponemos que la clave para explicar la complejidad del personaje de Alcibíades en Banq. radica en la descripción del alma del hombre-tiránico de Rep. VIII-IX, bajo el supuesto de la proximidad cronológica y conceptual de ambos diálogos. Esto nos permitirá mostrar que la conducta del Alcibíades del Banq. puede ser comprendida a la luz del alma del hombre-tiránico, en coincidencia con la pintura de un Alcibíades histórico aspirante a la tiranía. Para ello, en primer lugar haremos una semblanza del célebre general ateniense según los testimonios de Tucídides y Plutarco; en segundo lugar, expondremos las características del alma tiránica tal como es descrita en República; finalmente, integraremos todos estos elementos a fin de interpretar las palabras de Alcibíades en el Banq., intentando mostrar cómo Platón deja entrever allí, sutilmente, las características tiránicas o proto-tiránicas de su alma².

${ }^{1}$ Las traducciones de los textos griegos son nuestras.

${ }^{2}$ Hay quienes, como Finlay (1994, pp. 58-59), destacaron los posibles vínculos entre el alma democrática de Rep. VIII y el Alcibíades histórico, pero considerando a Alcibíades una transición entre la aristocracia y la democracia más que, como haremos nosotros, entre la democracia y la tiranía. Nichols (2007), por su parte, ha propuesto vincular los cargos de corrupción de jóvenes contra Sócrates en el juicio de 399 a.C. con los comportamientos del 


\section{El Alcibíades histórico}

La expedición ateniense a Sicilia del año 415 a.C. fue, sin dudas, uno de los hechos históricos que más visibilidad dio a Alcibíades. Según Tucídides, luego de que la asamblea decidiera enviar a Nicias, Lámaco y el propio Alcibíades como estategos al frente de la expedición (VI.8.2) ${ }^{3}$, el conflico surgió ante la negativa rotunda de Nicias a marchar a tierras sicilianas. El alegato de este último en contra de aquel permite entrever una serie de características de la personalidad de Alcibíades. En principio, Nicias alega que Alcibíades ha exhortado a la asamblea a que vote el viaje a Sicilia "observando su propio interés <sc. de Alcibíades>" (tò heautôu mónon skopôn $n$, VI.12.2.2), debido a que, en líneas generales, tal hombre es injusto en relación con lo público y derrocha lo privado ${ }^{4}$. Se trata, en definitiva, de un comportamiento típico de alguien demasiado joven (neóteros, VI.12.2.8), esto es, de alguien que toma decisiones sobre la base de su deseo apetitivo y no de la previsión racional: "son pocas las cosas que se completan correctamente a causa de la epithymía; muchas, en cambio, las que se completan a causa de la prónoia" (VI.13.1) ${ }^{5}$. A partir de esta referencia a la epithymía de Alcibíades, Tucídides articula una serie de rasgos caracterológicos: ante todo, que sus apetitos superaban su capacidad económica para satisfacerlos (VI.15.3). Pero lo más importante para nuestros intereses aquí es el hecho de que sus conciudadanos vieran en tales excesos apetitivos un rasgo asimilable al comportamiento de un tirano:

Alcibíades histórico en 415 a.C. En ninguno de los dos casos, como se ve, se hace un rastreo de las características del Alcibíades histórico en el personaje homónimo del Banq. platónico, cosa que haremos nosotros en el presente trabajo. Gribble (1999, pp. 246 ss.) compara al Alcibíades de Tucídides con el del Banq., pero tan sólo en términos del egotismo, ambición y vanidad de ambos, y a propósito del estilo paratáctico con el que se expresan. Quizás sea Larivée (2012), por último, quien más se acerque a una interpretación como la nuestra. No obstante, la autora no se centra, como haremos nosotros, en las particularidades caracterológicas del alma tiránica de Rep. (epithymía, paranomía, borrachera, etc.) para luego rastrearlas en el personaje del Banq.

${ }^{3}$ Según Plutarco, "Nicias fue elegido estratego involuntariamente, ya que huía del mando (arkhén) también a causa de su colega-general (synárkhonn). En efecto, a los atenienses les parecía que los asuntos de la guerra marcharían mejor si no lanzaban a un Alcibíades puro (ákraton), sino mezclando con su arrojo la previsión (prónoia) de Nicias” (Alc. 18.1). De inmediato se verá cómo Tucídides muestra la oposición entre Nicias y Alcibíades en términos de apetito e insensatez (epithymía, ánoia) el primero, y previsión (prónoia), el segundo.

${ }^{4}$ En Helénicas I.4.13 Jenofonte ratifica esta situación refiriéndose a la actitud del pueblo ante Alcibíades a su regreso del exilio a causa de la mutilación de los Hermes.

${ }^{5}$ Para el egoísmo como rasgo característico del tirano, cf. Aristóteles, Política 1279b, 1295a, 1311a; Heródoto III.80 y Seager (1957, \$II). 
La mayoría de los ciudadanos, temiéndole tanto por la magnitud de su transgresión (paranomía) $^{6}$ a propósito de su modo de vida en lo que a su propio cuerpo respecta, así como también por <la magnitud> de su inteligencia (diánoia) en cada una de las acciones que realizó, se hicieron enemigos de él, como si apeteciera la tiranía (họs tyrannídos epithymô̂nti). (VI.15.4)

A los ojos del común de la gente, en el célebre general convivían tanto una actitud transgresora en lo que a cuestiones corporales respecta, como cierta inteligencia o sagacidad en su comportamiento ${ }^{7}$. La razón por la que sus conciudadanos se volvieron sus enemigos resulta, pues, de la combinación de ambas cosas: paranomía y diánoia, esto eso: transgresión de la costumbre o de la ley (nómos) e inteligencia ${ }^{8}$. El Alcibíades de Tucídides se halla, pues, en cierto lugar intermedio entre la convivencia democrática - plasmada en esa inteligencia para cada una de sus acciones- y la desmesura apetitiva característica del tirano: "Alcibíades era un demagogo con el estilo de vida de un tirano" ". Esta coexistencia de dos fuerzas contrarias será, como veremos, una de las características fundamentales del alma del proto-tirano de República.

Estas vetas de tiranía son refrendadas por las palabras que Tucídides pone en boca del propio Alcibíades al momento de responder a Nicias: "me corresponde a mí, atenienses, más que a otros, mandar (árkhein)" (VI.161). Por otro lado, a propósito de la acusación de falta de previsión (prónoia) en pos de un comportamiento signado por los apetitos, comportamiento típico de jóvenes, el general justifica: "no es inútil la insensatez (ánoia) de aquel que sirve no sólo a los propios fines, sino también a la ciudad [...]. Y todas estas cosas $<s c$. los logros del pasado $>$ son producto de mi juventud y de una insensatez (ánoia) que parece estar más allá de la naturaleza (parà phýsin)" (VI.16.3-4 y 17.1, respectivamente $)^{10}$.

${ }^{6}$ El término "paranomía" remite etimológicamente a la transgresión de una costumbre o uso (nómos), de allí que sus traducciones posibles oscilen entre "transgresión (de una ley)", "ilegalidad" e, incluso, "perversión". Cada vez que hagamos referencia a él deben tenerse en cuenta, pues, estos matices.

${ }^{7}$ Plutarco cita explícitamente a Tucícides: “y Alcibiades no se preocupaba y era fácil de ser arrastrado por los placeres (pròs hédonàs agógimos); pues la 'su transgresión (paranomía) en lo que a su propio cuerpo respecta a propósito de su modo de vida' a la que se refiere Tucídides induce a tal suposicion" (Alc. 6.3).

${ }^{8}$ Para las paranomíai concretas que habría perpetrado Alcibíades (libertinaje, adulterio, abusos diversos, ambigüedad sexual, incesto, entre otras) cf. Lariveé (2012, p. 9 y referencias en nota 25$)$.

${ }^{9}$ Wohl (1999, p. 365; traducción nuestra).

${ }^{10}$ Con respecto a esta última cláusula, "parà phýsin dokoûsa eînai", entendemos que Alcibíades está siendo irónico al referirse, en su discusión con Nicias — quien lo ha acusado de obrar a partir de su ánoia-, a que, incluso en ese aspecto, es superior al común de los hombres. Otras traducciones son "que parece traspasar los límites de la normal naturaleza 
Finalmente, el episodio de la mutilación de los Hermes algunas noches antes de partir a Sicilia, termina de poner a Alcibíades en la mira ${ }^{11}$ :

$<$ Los atenienses $>$ dieron mucha importancia al asunto, pues parecía que era un presagio para la expedición y, al mismo tiempo, parecía perpetrado para una conspiración con vistas al derrocamiento de la democracia [...]. Hubo una denuncia, entonces, por parte de algunos metecos y servidores, no respecto a los Hermes, sino que tuvieron lugar ciertas mutilaciones de otras imágenes sagradas (agálmata) efectuadas anteriormente por jóvenes en un momento de juerga y vino (metà paidiâs kaì oínou) [...] Y de estas cosas acusaron a Alcibíades [...], agregando como prueba su otra transgresión no democrática (ou dẹmotikến paranomían) en relación con sus conductas. (VI.27.3 y $28.1-2)^{12}$

La "otra paranomía no democrática" a la que se hace alusión es la que comentamos supra a propósito de la desmesura apetitiva que hizo que los atenienses se volvieran enemigos de Alcibíades por considerar que aspiraba a la tiranía ${ }^{13}$. Pero a esta paranomía se agrega aquí el hecho de que los jóvenes que perpetraron los hechos estaban borrachos (metà oínou $)^{14}$. Como veremos más adelante, la borrachera es una de las características del alma del tirano de República y, como es bien sabido, del personaje de Alcibíades en el Banquete $e^{15}$.

del hombre" (J.J. Torres Esbarranch), “contraire à l'ordre naturel” (de Romilly), "qui paraît si incroyable" (Zevort).

${ }^{11}$ Para una referencia general a las estatuas de Hermes, cf. J.J. Torres Esbarranch, nota 75 ad VI.27.1.

${ }^{12}$ En palabras de Torres Esbarranch (2000, nota 77 ad VI.27.3): "si los culpables no eran encontrados y castigados, el sacrilegio podía recaer sobre toda la ciudad [...]; preocupaba, además, el gran número de Hermes mutilados, lo que hacía pensar en un numeroso grupo de participantes en aquel acto sacrílego que, al profanar imágenes sagradas muy queridas por los atenienses, permitía suponer que era el preludio de un verdadero ataque contra las instituciones y contra el régimen”. Cf. Plut., Alc. 20.5: “y, a los desmanes sobre los Hermes, sumaron también los de los Misterios, afirmando que obedecian a una sola conjura para subvertir el orden".

${ }^{13}$ Cf. VI.15.4. En Lisistrata, de Aristófanes, el Corifeo advierte al Prítanis: "sean sensatos y usen los mantos, no sea que los vea alguno de los que mutilaros los Hermes" (10931094). Para la presencia de Alcibíades en Aves de Aristófanes, cf. Vickers (1989).

${ }^{14}$ Cf. Plut. Alc. 19.1: “entre tanto, el orador Androcles presentó a unos esclavos y metecos que acusaron a Alcibíades y sus amigos de haber decapitado otras estatuas (agálmata) y haber imitado los Misterios bajo los efectos del vino (par' oînon)". Rosen (1987, p. 285) llega a afirmar que la noche del banquete platónico es la misma que la de la mutilación de los Hermes. Sin embargo, como bien señala Gribble (1999, p. 251, nota 116), esto resulta históricamente imposible debido a las fechas atestiguadas del triunfo de Agatón en las Leneas (Enero de 416 a.C.) y de la mutilación en cuestión (Mayo de 415 a.C.).

${ }^{15} \mathrm{Si}$ bien resulta un poco forzado decirlo, no deja de llamar la atención el hecho de que Tucídides hable de los "agálmata" que Alcibíades habría mutilado, cuando es ese mismo 
Transgresión de la ley, borrachera, pasión erótica e inteligencia. Las características del Alcibíades histórico son resumidas por Plutarco:

La inteligencia y habilidad (phronémati kaì deinótéti) que ponía en tales asuntos políticos y discursos <contrastaba> con la lascivia de su modo de vida y sus excesos de bebida y amores [...]. Al ver esto, los hombres más reputados, además de sentirse asqueados e irritados, temían su desdén y su transgresión-de-la-ley (paranomía), como siendo cosas tiránicas y extrañas (tyrannikà kaì allókota) (16.1-2)

\section{El hombre tiránico en República}

Sobre la base de la tripartición del alma humana y tras detallar la educación específica que debe recibir el filósofo gobernante, Platón avanza en los libros VIII y IX de República hacia el análisis de los distintos tipos de gobierno y, de manera concomitante, de las clases de almas que tendrán los ciudadanos de cada uno de tales regímenes. Haciéndose eco del así llamado "Principio de paralelismo estructural"16, cada régimen de gobierno coincidirá con la composición psíquica de quienes lo conforman. Así, aquellos en cuyas almas gobierna lo que debe gobernar, la parte racional, son hombres monárquico-aristocráticos; aquellos en quienes gobierna la parte impulsiva son hombres timocráticos; $y$, finalmente, aquellos en quienes gobierna la parte apetitiva son, o bien oligárquicos, o bien democráticos, o bien tiránicos ${ }^{17}$.

En el contexto teórico de República, la tiranía es producto del exceso de libertad propio de la democracia, régimen este último que se define como aquel en el que la multitud de pobres comparte por igual la totalidad de los cargos públicos, que se reparten por sorteo (557a). Tal ciudad está "colmada de libertad <de acción> y de libertad-de-palabra" (eleutherías mestè kaì parresías, 557b4-5), por lo cual cada ciudadano organiza su vida según su propio parecer; viven en ella, por lo tanto, "todos los caracteres humanos"

término el que utiliza Platón para referirse a aquello que Alcibíades ve en el interior de Sócrates: cf. Banq. 215b y 216e.

${ }^{16}$ Cf. Mársico-Divenosa (2005, pp. 40 ss., $\$ 5.1$ ).

${ }^{17}$ No nos extenderemos aquí en un análisis detallado de las partes del alma; para ello, remitimos a nuestro E. Bieda, "Unidad y multiplicidad del alma en la República de Platón", Quaderni Urbinati di Cultura Classica 104, 2014. Para el hombre monárquico-aristocrático, cf. Rep. 580b ss.; para el hombre timocrático, cf. 545d ss.; para el oligárquico, cf. 550c ss.; para el democrático, cf. 555b ss. Al hombre tiránico nos dedicaremos puntualmente en lo que sigue. 
(pánta éthe, $557 \mathrm{c} 6)^{18}$. El hombre democratico es, pues, variado, y su diversidad se plasma en las distintas clases de apetitos que tiene. En 558d ss. se esboza una primera clasificación de los apetitos que se irá completando en las páginas siguientes: los hay "necesarios" -i.e. los naturales o 'físicos', como el de beber cuando se tiene sed-y "no necesarios". El hombre democrático los tiene, al azar (týkhe $i, 561 \mathrm{~d} 4)$, a ambos: vive su vida satisfaciendo el apetito que le caiga en suerte. Así, un día se emborracha al son de la flauta y al día siguiente toma agua y hace dieta, holgazanea pero también vive como si filosofara, apoya a los militares al igual que a los hombres de negocios. El hombre democrático está, pues, gobernado por este plexo de apetitos variopintos:

$<$ Los apetitos del hombre democrático $>$ toman la acrópolis del alma del joven por percibirla vacía de conocimientos, ocupaciones y argumentos (lógon $)$ verdaderos, los cuales son, ciertamente, los mejores custodios y guardianes para los pensamientos de los hombres amados por los dioses [...]. Entonces, creo, argumentos y opiniones falsos e impostores, luego de correr a ubicarse en lugar de aquellos, ocupan su lugar. $(560 \mathrm{~b}-\mathrm{c})$

Nótese cómo en el alma del joven democrático hay conocimientos y argumentos verdaderos que, con el correr de la maduración democrática y el subsiguiente paso a la adultez, son desterrados de la acrópolis del alma por la acción de ciertos apetitos. No obstante, como Platón se encarga de aclarar, no son tales apetitos los que terminan gobernando en dichas almas, sino otros conocimientos y opiniones, pero falsos o “impostores" (alazónes). El hombre democrático pasa a ser, así, el paradigma del interlocutor con quien dialoga Sócrates en el ágora de la Atenas democrática: aquel que cree que posee conocimientos cuando, en realidad, tan sólo posee falsas opiniones.

El hombre tiránico surge, en este contexto, del exceso de libertad que genera la democracia, bajo el supuesto de que la aplicación excesiva de una acción determinada suele producir una acción contraria ${ }^{19}$. Es por ello por lo que el análisis del hombre tiránico requiere una mayor compledidad de la clasificación de los apetitos avanzada en la descripción del hombre democrático. Si en aquel momento bastó con distinguir entre apetitos necesarios y no necesarios, ahora se agrega que, entre los no necesarios, hay algunos que parecen innatos y que son imposibles de someter a toda forma

${ }^{18}$ Sobre esta definición de democracia en Aristóteles, cf. EN 1160a31-b22, Pol. III 8, IV 4 y VI 1-3, y Ret. 1365b31-1366a4. Para la diferencia entre la democracia griega y las modernas, cf. Canto-Sperber (2000, p. 203).

19 "De un modo verosímil, entonces, la tiranía no se impone a partir de ningún otro orden político que la democracia: a partir de la más alta libertad se impone, creo, la más amplia y salvaje esclavitud" (564a); cf. también 562c y 569b-c. 
de regulación o legalidad (paránomoi) ${ }^{20}$ : "pero cuando <estos apetitos> son castigados tanto por las leyes como por apetitos mejores acompañados de razón (metà lógou $)^{21}$, por un lado se apartan de algunos hombres o subsisten pocos y débiles, pero, en otros hombres, se tornan más fuertes y cuantiosos" (571b-c). La prueba de que tales apetitos existen son los sueños: dormida la parte racional del alma, libres, por lo tanto, de toda vergüenza y sensatez (aiskhýne kaì phrónesis, 571d1), estos apetitos bestiales y salvajes se lanzan a la satisfacción desmedida del carácter que les es propio. En el hombre tiránico habitan, pues, estos apetitos desenfrenados, aumentados y alimentados hasta el extremo, de modo tal que aquello que debería mandar en el alma, la racionalidad, es desplazado del gobierno:

Y si acaso <este hombre> encontrara dentro de sí ciertas opiniones o apetitos vueltos nobles y que todavía le generan vergüenza (éti epaiskhynoménas), los mata y arroja fuera de sí mismo hasta estar puro de moderación y llenarse de una locura foránea. (573b)

Esos apetitos nobles que aún habitan en el alma del proto-tirano son el lastre que arrastra de su pasado democrático: como dijimos, en el hombre democrático conviven toda clase de apetitos al azar, por lo que no todos esos apetitos son viles o innobles; en su alma también hay apetitos nobles ${ }^{22}$. Nótese, en este sentido, que la vergüenza opera como criterio para distinguir aquellos apetitos aún nobles: en el fondo del alma que se está tiranizando, ciertos deseos moralmente positivos intentan salvarse generando remordimiento y pudor en el hombre que sabe que el modo de conducta hacia

${ }^{20}$ De inmediato se precisará que se trata de "cierta forma terrible, salvaje y anómica (ánomon) de apetitos" (572b3-4). No nos parece acertado el comentario de Adam (1902, ad loc.) a propósito de la traducción del adjetivo "paránomos" en 571b4: "significa más bien 'antinatural' (unnatural) que 'anárquico' (lawless)”, dado que, como se verá en lo que sigue, estos apetitos ajenos a la legalidad serán castigados por la ley. Cf. 539a (oposición entre alguien "paránomos" y alguien "nómimos"), 572 b4 (ánomon epibymiôn eîdos), 587a1112, 607a (oposición entre hedoné y nómos). Interpretan como nosotros Mársico-Divenosa (“anárquicos”); Shorey, White, Reeve y Griffith ("lawless”), Leroux ("déréglés”) y Bultrighini-Caccia-Pegone ("illegittimi”).

${ }^{21} \mathrm{El}$ caso de ciertos apetitos nobles regulados por la razón es el del filósofo, en quien aquellos se subordinan a la norma impuesta por esta. Cf. de inmediato los "apetitos nobles" en $573 \mathrm{~b} 2$.

${ }^{22}$ Las epithymíai no son de por sí algo innoble y vergonzante: existen apetitos nobles (epithymíai khrestaí, 573b2). El término “epithymía” tiene, en el corpus platónico, dos significados básicos, ambos relacionados con alguna clase de hẹdoné (cf. Cárm. 167e y Rep. 436a-b): si bien alude generalmente a un deseo cuya satisfacción se vincula con placeres corporales (cf. v.g. Crát. 404a ss., Teet. 143e, Fedr. 232b y Lis. 221a), en algunas ocasiones se lo vincula con deseos intelectuales o, en sentido más ámplio, no físicos (cf. v.g. Teet. 143e, Banq. 187e, 200e y 205d, Fedr. 237d, Laq. 182b y 217e, Hip. May. 298e). 
el cual se encamina es vicioso. Frente a esto, el proto-tirano aniquila tales deseos y los arroja fuera del alma. De ese modo, también destierra aquel sentimiento que se erigía como último recurso de defensa ante el avance del mal: la vergüenza. En el alma del hombre en proceso de volverse tiránico hay, pues, cierto lastre de su pasado democrático que se materializa en el sentimiento de vergüenza frente a determinadas actitudes que adopta.

Finalmente, una locura fundada en la demanda permanente de objetos externos necesarios para dar satisfacción a sus apetitos — de allí que sea "foránea" (epaktós, 573b4) - custodia una racionalidad que es reducida a su mínima expresión, sin posibilidad ninguna de traducirse en actos según fines propios. Ahora bien, ¿de qué modo caracteriza Platón esta locura apetitiva del hombre tiránico?

¿Acaso, entonces, no es también Eros llamado 'tirano' desde hace tiempo por esto mismo? (573b)

El deseo que sobresale en este hombre que, nacido en un régimen democrático, ve su alma tiranizada por los apetitos debido al exceso de libertad del que goza, es el deseo erótico. En efecto, debido a la educación recibida por sus padres, en esta clase de hombres habita un Éros que se erige como prostáte en el alma ${ }^{23}$. Técnicamente, un prostáte no es cualquier clase de jefe, sino aquel que se alza como líder de los metecos ${ }^{24}$, esto es: ciudadanos de otra pólis que, por eso mismo, no son esclavos en Atenas, aunque tampoco ciudadanos de pleno derecho; participan de la dinámica de la pólis con ciertos derechos civiles, pero no participan del órgano de gobierno, es decir: carecen de derechos políticos. En el presente contexto, el Éros pasa a ser, dentro del alma, líder de los restantes deseos que, de modo equivalente a lo que ocurre con la ciudadanía en general en una tiranía y con los metecos en una democracia, dejan de tener derechos políticos dentro del alma, pasando a depender casi exclusivamente de la voluntad de su jefe. El alma del hombre tiránico está comandada por los designios de Éros: "un érós tirano pilotea, viviendo dentro <de ella>, absolutamente todas las cosas del alma" (573d), pues "conduce" (elaúno, 573e5) a los restantes deseos cohabitan en ella. En definitiva, el hombre tiránico es tal puntualmente por haber sido "tiranizado por Éros" (tyranneutheis hypò Érotos, 574e2), quien "vive en él tiránicamente (tyrannikôss) y en completa anarquía y anomia" (575a1)25.

${ }^{23}$ Cf. Banq. 197e1, donde Glaucón llama a Éros "parastátẹ" ("auxiliar de a bordo <en un barco>”).

${ }^{24}$ Cf. v.g. Aristóteles, Pol. $1275 \mathrm{a} 13$ y LSJ s.v.

${ }^{25}$ Cf. también 578 a, donde se describe al tirano como alguien "enloquecido por los apetitos y las -pasiones-eróticas (mainoménói hypò epithymiôn te kaì erótón)". Una situación 
Si bien esta caracterización negativa de érós podría resultar a primera vista llamativa, lo cierto es que la cultura griega aporta más de un ejemplo en el cual el amor no es visto como algo positivo, sino como fuente de desgracias. En el Encomio de Helena de Gorgias, la cuarta causa por la cual Helena puede haber marchado hacia su desastroso destino es justamente el éros. Lo interesante de esta concepción gorgiana de un éros causante de males para quien lo siente es que no se está hablando sólo del dios, sino también del hecho de que sea una "enfermedad humana e ignorancia del alma" (anthrópinon nóséma kaì psykhêes agnóéma, $\$ 19)^{26}$. El amor como enfermedad que aqueja las almas sumiéndolas en la ignorancia es algo que resuena sensiblemente en la concepción del tirano que estamos viendo en Rep. La prueba de que Platón conoció esta concepción negativa del éros la hallamos en el libro I de la propia Rep.:

Una vez estaba junto a Sófocles, el poeta, cuando fue interrogado por alguien: “En qué estado estás, Sófocles, en relación con los placeres sexuales (tà aphrodísia)? ¿Todavía eres capaz de estar con una mujer?”. Y él respondió: “¡Cállate! Escapé de eso con muchísimo gusto, como quien huye de cierto amo (despótenn) rabioso y salvaje”. (329c)

Si el érós del libro IX era caracterizado como "tirano", el del libro I es considerado un "amo" (despótes) salvaje que hace que un hombre sabio como Sófocles agradezca, ya viejo, haber podido escapar de él. Enfermedad, tiranía y salvajismo en un sentimiento erótico que aleja a su portador del camino de la sabiduría y lo sume en la ignorancia. En esta misma línea, en el Hierón de Jenofonte se dice algo más que relevante para nuestro trabajo: "es probable que los goces de los placeres sexuales (hai tôn aphrodisión apolaúseis) traigan aparejados los deseos de ser tirano, pues en la tiranía es posible estar con aquel a quien vieras más bello” (I.26). Una de las causas de la tiranía se hallaría, como se ve, en la posibilidad de elegir discrecionalmente compañeros sexuales. La relación entre éros y tiranía está, pues, atestiguada en diversos contextos más o menos contemporáneos a Platón. En palabras de Larivée: "en la medida en que la tiranía es asociada con cierta tendencia a utilizar el poder político con fines eróticos, la presencia de pasiones desenfrenadas en un líder político era, a los ojos de los atenienses, suficiente para sospechar de él y acusarlo de tener ambiciones tiránicas”27.

similar a esta se da en Prot. 352b-c donde se describe la posición de quienes consideran que la incontinencia es posible en términos de érós gobernando (árkhein) sobre la epistéme.

${ }^{26}$ Algo similar ocurre con el personaje de Fedra quien, en el Hipólito de Eurípides, denomina "enfermedad" (nósos) a su funesto amor por su hijastro Hipólito (v. 394), amor que, como es sabido, acabará con su vida y con la del propio Hipólito.

${ }^{27}$ Larivée (2012, p. 7; traducción nuestra). 
Pero el imperio de Éros no es la única característica del alma tiránica:
Entonces, amigo, ¿no ocurre también que el hombre que se emborrachó (methystheís anér) tiene cierta mentalidad tiránica? [...] El hombre se vuelve tiránico, hablando con precisión, toda vez que, o bien por naturaleza, o bien por sus conductas, o bien por ambas cosas, se vuelva borracho y erótico (erotikós), es decir: un loco (me- lankholikós). (573c)

A la tiranía erótica se suma la borrachera como otra de las instancias características del hombre tiránico ${ }^{28}$. El hombre afín a la pasión erótica desenfrenada y a la bebida es, en definitiva, un melancólico enloquecido por la pasión ${ }^{29}$. Algunas décadas luego de la escritura del Banq., Aristóteles volvería a vincular la melancolía, la borrachera, los apetitos y la excepcionalidad política:

¿Por qué todos cuantos resultan hombres extraordinarios (perittố), ya sea en relación con la filosofía, con la política, con la poesía o los oficios técnicos, parecen ser melancólicos? [...] El vino en grandes cantidades parece predisponer como tales a aquellos que decimos que son melancólicos [...]. <Los melancólicos $>$ son eróticos (erotikoî) y fácilmente movidos por los apetitos (eukýnetoi pròs tàs epithymías). (Probl. XXX, 953a10-13; 33-34; 954a33) ${ }^{30}$

\section{El canto de la sirena socrática en el Banquete}

\section{a) El alma tiránica de Alcibíades en el Banquete}

El Alcibíades del Banq. es un personaje complejo. Sin embargo, si tenemos en cuenta los lineamientos generales de la descripción del hombre tiránico dada en Rep. VIII-IX, dicha complejidad parece organizarse en torno a un perfil psíquico-político determinado. En principio, las tres características distintivas del hombre tiránico de Rep. parecen darse sin más en el Alcibíades del Banq.: el éros, la borrachera y la locura. El propio Sócrates le comunica a Agatón su temor, por cuanto Alcibíades "celoso y envidioso de mí, hace cosas raras, me injuria y apenas si aparta sus manos <de mí> [...] Si acaso intentara hacerme algo violento, ayúdame, puesto que yo temo

\footnotetext{
${ }^{28}$ Para la presencia de la borrachera en los diálogos platónicos, cf. Fallas (2008).

${ }^{29} \mathrm{El}$ sustantivo melankholikós no debe interpretarse, en este contexto, con el significado que acabó teniendo en nuestras lenguas modernas. LSJ traen s.v. para este pasaje de Rep. "atrabilious", "impulsive". Algunas traducciones posibles -intentando evitar el equívoco que podría generar traducir "melancólico" sin más (Mársico-Divenosa, Leroux y Reeve)— son "insane" (Adam), "lunático" (Eggers Lan), "mad" (Griffith). Esta interepretación hace eco con Ética nicomaquea 1152a19, donde Aristóteles afirma que "el melankholikós no es en absoluto capaz de deliberar"; precisamente, porque es prácticamente un lunático.

${ }^{30}$ Para el melancólico como "bybristés", cf. 953b4; como "lágnos", cf. 953 b33.
} 
mucho su locura (manía) y devoción erótica (philerastía)" (213d). Estos celos, envidia, locura y devoción erótica, sumados a la borrachera, se erigen, así, como los resortes fundamentales en los que descansan las acciones de Alcibíades desde su entrada al banquete. Ahora bien, ¿se trata sólo de una coincidencia o, junto con estos tres rasgos, es posible hallar otros aspectos tiránicos en el personaje?

Superada esta presentación inicial, es interesante destacar el modo en que Alcibíades se ubica a sí mismo en el marco de la reunión que ya estaba teniendo lugar antes de su llegada. Tras constatar (o, más bien, denunciar) que todos están sobrios, afirma: “¡No se puede ceder ante ustedes! ¡Hay que beber! [...] Me elijo a mí mismo como jefe de la bebida (árkhonta hairoûmai tês póseós emautón)" (213e ${ }^{31}$. Alcibíades irrumpe repentina e intempestivamente (exaíphnes, 212c) en una reunión cuyo funcionamiento ya ha sido pactado con anterioridad y, desconociendo de facto tales convenciones, se autoproclama "jefe" (árkhon $n)$ y ordena beber desaforadamente como curso de acción a seguir ${ }^{32}$. Recuérdense, en este sentido, las palabras que Tucídides pone en boca del célebre general frente a la asamblea: "me corresponde a mí, atenienses, más que a todos, mandar (árkhein)” (VI.161). El intento de imponer la propia voluntad — voluntad orientada, a su vez, por una determinación eminentemente irracional-apetitiva como es el hecho de beber- por encima del consenso colectivo que había acordado una actividad de corte intelectual como la que ha tenido lugar durante la reunión, delinea el trazo tiránico que el personaje platónico presenta desde su aparición ${ }^{33}$.

Sin embargo, el personaje del Banq. platónico no presenta, a nuestro entender, las características definitivas del alma tiránica, sino que se trata, más bien, de aquel hombre que se halla en transición desde un pasado democrático hacia un futuro tiránico ${ }^{34}$. Según vimos en Rep. 573b citado

${ }^{31}$ De inmediato, Alcibíades dirá a un sirviente que le alcance un balde de más de dos litros lleno de vino y se lo beberá entero. Esta insaciablidad evoca la imagen del "tonel sin fondo" o con fondo agujereado que caracteriza el alma del tirano en el Gorgias 493a ss.

${ }^{32} \mathrm{El}$ acuerdo inicial respecto del beber había consistido en no conducir la reunión a través del camino de la borrachera (dià méthệs), sino beber con vistas al placer (176d-e). La propuesta, refrendada por Fedro, había sido del médico Erixímaco.

${ }^{33}$ Comenta Gribble al respecto: "para los griegos, el control cuidadoso de la bebida era un índice de la habilidad para contener los placeres físicos, considerando el beber sin control un signo peligroso y bárbaro. La destitución tiránica de Alcibíades del democráticamente elegido jefe del simposio es paralela, así, a su actitud cívica” (1999, p. 251; traducción nuestra).

${ }^{34}$ Resulta interesante la tesis de Gribble, quien sostiene que el parlamento de Alcibíades es una segunda apología de Sócrates que Platón escribe contra el panfleto de Polícrates. Lo 
supra, en un alma de esta clase aún sobreviven ciertos deseos nobles. Esta, creemos, es la situación del alma de Alcibíades, sumamente permeable a las palabras de Sócrates, pero no del modo en que sus otros discípulos son convencidos o problematizados por ellas, sino en términos de un efecto que linda con el encantamiento. Además de "impresionarlo" (ekpeplegménos) y "someterlo" (katékhesthai), escuchar sus discursos hace que su corazón corra más que los de los poseídos por los coribantes, hasta el punto de romper desconsoladamente en llanto: "y todavía hoy me tengo bien sabido que, si quisiera prestarle mis oídos, no podría contenerme (karterésaimi), sino que padecería (páskhoimi) las mismas cosas [...]. Entonces, cerrando mis oídos mientras huyo, escapo por la fuerza (biai), como de las sirenas, no sea cosa que termine envejeciendo sentado junto a él" (216a). El canto de la sirena socrática pronuncia discursos que el alma de Alcibíades, intelectualmente débil, no puede incorporar sino emocionalmente. Cabe destacar que Alcibíades no está haciendo referencia a discursos amatorios que Sócrates pudiera dirigirle, sino a sus conversaciones y discusiones habituales: aquello que en Simmias o en Cebes genera reflexión e inquietudes dialécticas, en Alcibíades genera llanto y desesperación erótica tales que la única manera de evitarlos es la huida, la anulación de la escucha (y de la visión) o, como se decía en Rep. 573b citado supra, la expulsión de los deseos nobles que dieron lugar a tal escucha. Porque, cabe destacarlo: Alcibíades escucha a Sócrates porque quiere; nadie lo obliga a hacerlo. De allí se puede colegir que, al igual que en el caso del alma democrática en vías de tiranización, habitan en su interior ciertos deseos nobles que, al entrar en contradicción con aquellos otros, viles, que pretenden tiranizar el alma toda, dan lugar al llanto y la desesperación. De allí que la fuerza motriz capaz de operar para evadir esta situación no sea la reflexión, sino la fuerza (bía). El marinero que se halla frente a la sirena sólo puede huir de su encantamiento por la fuerza: mientras de su decisión dependa, se quedará allí, hipnotizado, o sucumbirá en las profundidades del océano intentando alcanzar al ser maravilloso. Paralelamente, Alcibíades se confiesa incapaz de escuchar sin padecer los efectos cuasi enloquecedores de un canto que sólo puede evitarse mediante barreras materiales: taparse los oídos o huir. Ambas cosas, no obstante, por la fuerza, dado que, si de la decisión de Alcibíades dependiera, allí se quedaría.

que esta segunda defensa mostraría es, entre otras cosas, que "lejos de corromper a Alcibíades, Sócrates fue el único que trató de evitar que se convirtiera en la clase de figura que devino más tarde" (1999, p. 245; traducción nuestra). 
Cabe mencionar, por otro lado, que la juventud del proto-tirano de Rep. se caracteriza por la experiencia de abundantes deseos satisfechos — debido a la educación recibida por su padre democrático, exhultante de libertad ${ }^{35}$ - , lo cual resulta en una personalidad incapaz de lidiar con la insatisfacción. A propósito de esto, si en Rep. Platón se sirve de la imagen de la picadura de un zángano, en Banq. Alcibíades compara los discursos filosóficos de Sócrates con una víbora:

Yo, mordido por algo más doloroso y en el más doloroso de los lugares donde alguien podría ser mordido —el corazón, el alma o como se lo deba llamar-, golpeado y mordido por los discursos filosóficos, que son más salvajes que una víbora, toda vez que captan el alma de un joven naturalmente talentoso, y hacen que haga y diga cualquier cosa. (217e-218a)

En este punto de su alocución, Alcibíades ya ha dicho que, de joven, había creído que Sócrates tenía interés en su belleza, y que tal cosa era algo sumamente afortunado y maravilloso para él (217a). Sin embargo, Sócrates lo rechazó una y otra vez, dejando su deseo insatisfecho: "me menospreció, se burló de mi juventud y me injurió (býbrisen)" (219c).

Hay que sumar a esta serie de ultrajes algo fundamental: Sócrates deshonró (étimásthai, 219d4) a Alcibíades, le quitó su honor propio. Esto, viniendo de alguien que, a los ojos de Alcibíades, tenía suprema sabiduría y fortaleza (phrónesin kaì karterían, 219d6), resulta determinante para personalidades como la del proto-tirano de Rep., incluso antes de tener cargos de gobierno:

Estos hombres $<s c$. los de alma tiránica> se vuelven así en su vida privada, incluso antes de gobernar. En primer lugar, <a propósito de aquellos> con quienes pudieran vivir: o bien viven rodeados de aduladores preparados para servirlos en todo, o bien, si acaso necesitaran algo, arrojándose ellos mismos <a los pies de otro>, atreviéndose a adoptar cualquier pose, obran como si fueran parientes (oikeîoi). (Rep. 575e-576a)

Alcibíades, incapaz de satisfacer su deseo con otro hombre que no fuese Sócrates, llega al punto de humillarse ante él para conseguir sus favores eró$\operatorname{ticos}^{36}$. Sin embargo, Sócrates lo deshonra. ¿Dónde, en ese caso, recuperar la honra perdida frente al hombre sabio y fuerte? En la multitud: "toda vez que me alejo <de él>, soy vencido por el honor que dispensa la multitud

${ }^{35}$ Cf. $573 \mathrm{a}-\mathrm{b}$, "Entonces, toda vez que los otros deseos zumbaran alrededor de él, llenos de inciensos, mirra, coronas, vinos y de placeres disolutos presentes en tales compañías, aumentándolos y alimentándolos hasta el extremo, clavan en el zángano <sc. el alma> el aguijón del deseo. Entonces, ese jefe (prostáte ) del alm es escoltado por la locura y pica".

36 "Estaba verdaderamente azorado (ํppóroun); iba de un lado a otro esclavizado ( $k a-$ tadedouloménos) por este hombre como nadie había sido esclavizado por ningún otro" (219e). Cf. también 219b-d. 
(hêttẹménói tệs timês tệs hypò tôn pollônn)" (216 b-c). Se va configurando, así, un hombre cuya personalidad sucumbe ante las adulaciones y supuestos honores públicos: del Éros tiránico asociado a la figura de Sócrates a la frustración y, de allí, a la satisfacción compensatoria que dispensa la mayoría.

Cabría preguntarse, en este punto, en qué sentido las palabras de quien ha argumentado sistemáticamente en contra de la tiranía ${ }^{37}$ pueden conmover de manera tal a quien, como adelantamos, habría tenido manifiestas aspiraciones tiránicas. En todo caso, hubiésemos esperado una reacción violenta como la de Calicles o Trasímaco, pero difícilmente lágrimas, emoción y ganas de huir intentando escapar del hechizo ${ }^{38}$. En concreto: ¿qué clase de sentimiento produce el llanto y la desesperación de Alcibíades al escuchar a Sócrates pronunciar sus discursos, en muchos casos, enemigos de la tiranía?

Sólo frente a este hombre he padecido lo que nadie podría creer que existe en mí: sentir vergüenza frente a alguien (aiskhýnesthai hontinoûn). Sólo ante él me avergüenzo, pues tengo bien sabido que soy incapaz de contradecirlo a propósito de que no debe hacerse lo que él ordena. $(216 \mathrm{~b})^{39}$

Si comparamos este pasaje con Rep. 573b citado supra, vemos que la vergüenza se vuelve el denominador común entre Alcibíades y el prototirano, por cuanto ambos conservan aún ciertos apetitos nobles que chocan sistemáticamente con las decisiones viciosas que la otra pléyade de deseos los conmina a tomar: "y menospreciándose a sí mismo, pero admirando a Sócrates, apreciando su amistad y avergonzándose ante la virtud (aiskhynómenos tèn aretén), sin darse cuenta adquirió una imagen de amor" (Plut., Alc. 4.4). Se ve, pues, cómo el célebre general es caracterizado como un hombre atravesado por el conflicto interno: ama los honores y el poder, pero al mismo tiempo no puede evitar reconocer el valor de la vida filosófica que profesa y practica Sócrates. Si la coherencia o racionalidad interna es un rasgo característico de las almas en las que gobierna la razón ${ }^{40}$, el caso del Alcibíades parece ser el de aquel en el que dicho gobierno está siendo

${ }^{37}$ Cf. v.g. Gorgias passim y Rep. I.

${ }^{38}$ Según Gribble, “a diferencia de Calicles, que rechaza de plano lo que Sócrates tiene para decir, Alcibíades se presenta a sí mismo como alguien profundamente atraído por sus palabras [...]. Se trata de un magnánimo Alcibíades que se defiende 'heroicamente' ante Sócrates pero, al hacerlo, es reducido y vencido" (1999, p. 244; traducción nuestra).

${ }^{39} \mathrm{La}$ 'prueba' de que Alcibíades sentía, frente a todos los demás hombres (salvo Sócrates), una superioridad tal que hacía imposible que sintiera vergüenza frente a ellos se puede ver en Tucídides VI.16.1 (áxios), VI.16.4 (heautôi méga phronoûnta mè íson eînai) y VI.17.1, y en el propio Banq. 217a5-6.

${ }^{40}$ Para la "racionalidad interna" como rasgo del alma ordenada conforme la razón, cf Vigo (2002). 
disputado por deseos emanados de otra esfera, no racional. Según vimos supra, el hombre en el que gobierna esta clase de deseos apetitivos es aquel a quien Platón denomina "tirano".

Si tanto Tucídides como Plutarco y el propio Platón destacan las cualidades moralmente negativas de Alcibíades, ¿cómo explicar que haya pasado tantos años junto a Sócrates, que este último lo haya contado entre sus discípulos e, incluso, haya llegado a ser su amante? ¿Pudo Sócrates convivir con alguien con las cualidades morales de Alcibíades? Jenofonte explica esta cuestión:

Critias y Alcibíades, mientras estuvieron junto a Sócrates, pudieron gobernar (edynásthen krateîn) sus malos apetitos sirviéndose de aquel como aliado. Sin embargo, tras apartarse de él, [...] Alcibíades, acechado por muchas mujeres distinguidas a causa de su belleza, destrozado (diathryptómenos) por muchos y poderosos hombres a causa de su poder, tanto en la ciudad como entre los aliados, honrado por el pueblo y ocupando fácilmente el primer lugar [...], se descuidó a sí mismo (êmélsesen hautôิ). Dándose en ellos <sc. Critias y Alcibíades> tales cosas: exaltados por su estirpe, magnificados por su riqueza, hinchados por su poder, destrozados por multitud de hombres y habiendo estado por mucho tiempo separados de Sócrates, ¿qué hay de asombroso si se volvieron arrogantes (hyperephánó)? (Mem. I.2.24-25)

El pasaje de Jenofonte ratifica no sólo el dominio que las epithymíai ejercían sobre Alcibíades, sino también el rol desempeñado por el honor dispensado por las multitudes que, magnificando e hinchando de soberbia su persona, hicieron que él mismo se descuidara de sí, trocando en arrogancia la naturaleza filosófica que Sócrates había visto en él.

Por último, como nota de color, detengámonos un momento en el comienzo del encomio que Alcibíades dedica a Sócrates:

Afirmo que Sócrates es bien semejante a esos silenos que están sentados en las tiendas de estatuas. (215a-b)

El término que hemos traducido "tienda-de-estatuas" es "hermoglyphêิon", literalmente: "tienda de <estatuas de> Hermes". Si bien es cierto que en el siglo IV el término ya había adquirido el sentido genérico de "tienda de estatuas" 41 , no es menos cierto que el hecho de que sea Alcibíades quien lo utiliza en su primera caracterización de Sócrates no deja de ser sugerente, sobre todo para un lector que conoce bien el episodio de los Hermes previo a la partida de la expedición a Sicilia y las sospechas que recayeron sobre la figura de Alcibíades. Si recordamos, asimismo, que los jóvenes que mutilaron esas y otras estatuas habrían estado borrachos, recién salidos de un banquete (cf. Tucídides VI.27.3 y 28.1-2), resulta que el

${ }^{41}$ Cf. Brisson (2007, nota 526). 
personaje platónico del Banq. encaja casi perfectamente en la imagen que el siglo IV heredó del célebre general.

\section{b) ¿Alcibiades incontinente?}

Si, como vimos, el único modo que tiene Alcibíades de evitar caer en el encantamiento de los lógoi socráticos es la fuerza, es decir: no escuchándolos; dicho de otro modo: si Alcibíades sabe que no quiere hacer lo que los argumentos de Sócrates le indican pero, no obstante, no puede evitar hacerlo cuando los escucha, ¿significa eso que estamos ante cierta clase de comportamiento incontinente?

Decía el acusador que Sócrates tuvo dos discípulos, Critias y Alcibíades, que hicieron multiplicidad de males a la ciudad, pues Critias fue el más codicioso y violento de todos <los hombres> en la oligarquía, y Alcibíades, a su vez, el más incontinente e insolente (akratéstatós te kaì hybristótatos) de todos en la democracia. (Memorabilia I.2.12)

En el alma tiránica se da un extremo de complejización psíquica tal que llega a rozar la rutptura con el así llamado "Intelectualismo socrático", por cuanto en ella domina la irracionalidad ${ }^{42}$. Si en el alma democrática el influjo de la irracionalidad es cada vez mayor pero, no obstante, sigue siendo la razón la que, aun equivocada, engañada u obligada, gobierna, en el alma del tirano encontramos una novedad: la razón ya no gobierna, sino que lo hacen los apetitos irracionales:

A las opiniones acerca de lo noble y lo vergonzoso que tenía antiguamente desde chico -opiniones tenidas por justas- las dominarán (kratésousi), con la compañía de Eros, a quien escoltan, los apetitos recién liberados de la esclavitud, <apetitos> que originalmente se liberaban <sólo> mientras dormía, en los sueños, cuando todavía era democratizado dentro de sí mismo por las leyes y por su padre. (574d-e)

Según vimos, los variados apetitos del hombre democrático usurpan el lugar de los argumentos y conocimientos verdaderos e instalan principios falsos, es decir: engañan a la razón que, gobernante, cree estar persiguiendo parámetros verdaderos cuando, en realidad, no lo hace. En el alma del

${ }^{42}$ No nos extenderemos aquí en los pormenores del "Intelectualismo socrático". Demos por sentado el hecho de que sostenga la imposibilidad fáctica de que las decisiones de un agente sean tomadas en contra de lo que su saber o su opinión sostengan como la mejor alternativa a seguir, en principio para sí mismo, y entre las posibles. Esto implica que mandatos irracionales como los de los apetitos no pueden imponer un curso de acción, a menos que sean refrendados por la racionalidad. De este modo, todo error en la esfera práctica se explica en términos de una falla cognitiva. Para este tema, cf. Protágoras 352b-c y 358b, y especialmente E. Bieda, "Creer o saber, esa no es la cuestión. Opinión y conocimiento en el Protágoras de Platón”, Circe de clásicos y modernos XV, Santa Rosa, Miño y Dávila, 2011. 
hombre tiránico, en cambio, tiene lugar el dominio (kratésousi, 574d8) de los apetitos sobre las opiniones tenidas por justas desde la infancia. Así, el hombre tiránico hace lo que su deseo irracional, poderoso motivador que somete desenfrenada y salvajemente a la razón, le ordena ${ }^{43}$. Hay quienes opinan estamos ante una acción incontinente: "el alma cuyos elementos son revelados [...] resulta ser un alma susceptible de padecer un tipo particular de conflicto interno que es la debilidad de la voluntad (weakness of will), un fenómeno ahora entendido no en tanto error intelectual sino, de un modo más realista, como la derrota de un buen juicio cuando entra en conflicto con un deseo que demuestra ser un motivador más poderoso" ${ }^{44}$. No obstante, afirmar que el tirano, hombre malvado por definición, es un incontinente resultaría, a nuestro entender, un tanto excesivo. Ya hemos visto cómo las opiniones que el incipiente hombre tiránico tenía por justas desde la infancia son obturadas y esclavizadas por los apetitos que, así, se alzan como gobernantes del alma toda e imponen sus fines: "¿no es necesario que su alma esté llena de una esclavitud total y falta de libertad, y que esas partes suyas que eran las más nobles (epieikéstata) estén esclavizadas (douleúein) y que lo más malvado y alocado gobierne despóticamente (despózein) [en pequeño]?” (577d) ${ }^{45}$. No obstante, dichas opiniones tenidas otrora por justas son lo suficientemente acalladas como para no poder siquiera contradecir a los apetitos gobernantes: a diferencia de lo que ocurre en las almas oligárquicas y democráticas, en el hombre tiránico no hay conflictividad interna. Nótese que, a diferencia de lo que ocurría con el hombre democrático, en el alma tiranizada los apetitos no reemplazan las opiniones verdaderas por otras falsas, sino que imponen sus propios fines tornando inoperantes dichas creencias racionales en lo que a la toma de decisiones concretas respecta. Es por ello por lo que el dominio (kratésousi, 574d8) de los apetitos sobre las opiniones del agente no debe interpretarse como

${ }^{43}$ Esto supone, desde ya, que la parte apetitiva pueda establecer, ella misma, fines del actuar. Si bien de manera limitada, "un mínimo de cognición está implicado incluso en el apetito más elemental” (Kahn, 1987, p. 85; traducción nuestra) o, de modo similar, de que "cada parte <del alma> se organiza según creencias generales acerca de ciertos bienes [...]; parece probable que cada parte describa su propio fin como un bien intrínseco <a sí misma>" (Lesses, 1987, p. 151; traducción nuestra).

${ }^{44}$ Ferrari (2007, p. 169; traducción nuestra). En la misma línea, cf. Lesses (1987, p. 148). Lo que estas interpretaciones descuidan es el hecho de que la racionalidad pueda ser 'engañada' por las partes irracionales y, creyendo que hace lo mejor para el agente, obra de un modo perjudicial.

${ }^{45}$ Omitimos "smikrón" en $577 \mathrm{~d} 4$ porque tiene que ver con un contexto que no hace a los fines de la cita: se trata de que lo más malvado gobierna a las otras dos partes "en pequeño", i.e. en el alma humana en tanto versión pequeña de la pólis. 
una situación acrática -i.e. una situación en la cual el agente, a sabiendas, obra en contra de lo que considera mejor para sí mismo-, sino como el triunfo avasallante y violento de lo apetitivo que, sin recurrir a ninguna clase de persuasión, somete y reduce a la racionalidad al mínimo necesario para que el tirano, con todo, siga siendo un hombre y no se transforme en un loco $^{46}$. El tirano, casi literalmente, no sabe lo que hace, pero no porque obre engañado y lo que cree saber es, en realidad, una apariencia de saber, sino porque el saber no cumple ningún rol en la génesis de sus decisiones. Es esta reclusión profunda que padece la racionalidad del hombre tiránico la razón por la cual Platón lo considera prácticamente un loco (cf. "manía", 573a8, b4; y “mainómenos hyp’ epithymiônn”, 578a11).

Volviendo al caso de Alcibíades, hemos visto cómo las palabras de Sócrates 'activan' esas opiniones y deseos nobles legados de su pasado democrático, despertando el sentimiento de vergüenza ante su modo de comportarse. Así, aun borracho y movido por sus apetitos, Alcibíades no obra en contra de sus opiniones acerca de lo mejor, sino que, al borde de la locura erótica, encuentra quizás en la bebida la única manera de decir a Sócrates sus verdades.

\section{Conclusión}

Borrachera (Rep. 573c; Banq. 212d, 213e, 214a), un éros tiránico (Rep. 573d-575a; Banq. 213e, 217e-218a, 219e), vergüenza ante los propios actos (Rep. 573b; Banq. 216b): el Alcibíades del Banq. parece recoger varias de las características del hombre que, en Rep., está haciendo el tránsito desde un pasado democrático a un futuro tiránico. Ese pasado coincide, por lo demás, con los momentos en que Alcibíades disfrutó de la compañía de Sócrates, de sus enseñanzas y consejos: evidentemente, Sócrates vio en el célebre general alguien con capacidad para la filosofía. Su corrupción política puede ser puesta a la par, pues, de cierta corrupción intelectual o filosófica. Sócrates discute el problema de la corrupción de una naturaleza filosófica en el libro VI de Rep. Allí afirma que "si la naturaleza propia del filósofo que establecimos da con la enseñanza adecuada, es necesario que llegue a incrementarse hasta una completa perfección, pero toda vez

${ }^{46}$ Según Carone, “la razón es 'dominada' no en el sentido de que el agente realiza la acción mientras, al mismo tiempo, cree fuertemente que no debería hacerlo, sino en el sentido de que, en ese momento, su razón ha sido debilitada y ha adoptado las creencias de la parte que prevalece” (2001, p. 138). 
que, sembrada y plantada, es alimentada con una educación inadecuada, se incrementa hacia lo totalmente contrario" (492a). Pero un hombre de naturaleza filosófica, con falicidad para el aprendizaje (eumátheia), memoria, valentía y grandeza, deberá afrontar otra serie de problemas al llegar a la adultez: sus familiares y conciudadanos "yacerán <ante él>, exigiéndole y honrándolo (timôntes), anticipándose y adulando su futuro poder" (494c). Ya hemos visto cómo en Banq. 216 b-c Alcibíades dice haber sido "vencido" (hêttómenos) por el honor (timé) que dispensa la multitud; y luego, cómo Jenofonte hablaba de un pueblo que, con sus adulaciones (bypò tôे démou timómenos, I.2.24.8), acabó por hacer que se olvidara de sí mismo. Volviendo a la corrupción de las naturalezas filosóficas en Rep. VI, continúa Sócrates:

¿Y qué crees que hará una persona tal en tales circunstancias $<s c$. ante la adulación de las multitudes>, si, por lo demás, es casualmente oriundo de una gran ciudad, en la que es rico y noble, además de apuesto y fornido? ¿Acaso no se colmará de una esperanza extraordinaria, creyendo que será capaz de realizar las cosas de los griegos y de los bárbaros? ¿Y no se alzará, por estas cosas, él mismo como alguien orgulloso, colmado de un aspecto y un pensamiento vacuos, sin inteligencia? (494 c-d $)^{47}$

El hombre potencialmente filósofo puede desviarse fácilmente de su camino, seducido por la adulación de la mayoría y la esperanza de un poder absoluto en el futuro cercano. Si este desvío es, en definitiva, hacia el extremo "totalmente contrario" (pánta tanantía, 492a4) a la naturaleza filosófica —donde gobierna la racionalidad-, podemos pensar que Platón tienen en mente un alma tiránica.

Admitida la posibilidad de que una naturaleza filosófica degenere en su contrario, el vínculo de Sócrates con Alcibíades se vuelve verosímil: a una juventud signada por la filosofía y la búsqueda de conocimientos, siguió una maduración atravesada por las ansias de poder y el ensanchamiento de la vanidad, la arrogancia y el desenfreno apetitivo. El personaje que Platón incluye en el Banq. parece ser la versión extrema de esto último, la de quien, borracho, lamenta no poder dejar de ceder a la contundencia filosófica de los discursos de Sócrates, lo cual le genera vergüenza, a la vez que tampoco puede dejar de ceder al honor dispensado por la multitud. A esto se suma un desengaño amoroso que, según su protagonista, terminó por alejarlo de quien le impedía caer en las zonas más oscuras de su ser. Según testimonia Plutarco en el epígrafe del presente parágrafo, Alcibíades habría vivido de ese modo hasta el final de sus días, encontrando la muerte debido a su incontinencia apetitiva.

\footnotetext{
${ }^{47}$ Para la traducción de "hypselós” por "feliz”, cf. LSJ s.v., donde se cita este pasaje.
} 


\section{Bibliografía}

Adam, J., The Republic of Plato, Cambridge, CUP, 1902.

Bieda, E., "Unidad y multiplicidad del alma en la República de Platón", Quaderni Urbinati di Cultura Classica 104, 2014.

—, “¿Es Leoncio un incontinente? Ira y apetito en la República de Platón”, Diánoia LXIX, México D.F., Fondo de Cultura Económica, 2012.

—, "Boceto de una desintegración psíquica en el Gorgias de Platón", Hypnos XXIX, San Pablo, Editora da PUC-SP, 2012.

- "Creer o saber, esa no es la cuestión. Opinión y conocimiento en el Protágoras de Platón”, Circe de clásicos y modernos XV, Santa Rosa, Mi-o y Dávila, 2011.

Brisson, L., Platon. Le Banquet, Introduction, traduction et notes, Paris, Flammarion, 2007.

Burnet, J., Platonis Opera, Oxford, OUP, Tomus II, 1901 (repr. 1964).

Bury, R.G., The Symposium of Plato, Cambridge. W. Heffner and Sons, 1909.

Canto-Sperber, M. (ed.), Filosofía griega, Vol I, Buenos Aires, Docencia, 2000.

Cooper, J.M., "Plato's theory of human motivation", History of philosophy quarterly I, 1, pp. 3-21, 1984.

Dover, K.J., Edition and Commentary on Plato's Symposium, Cambridge, CUP, 1980.

Fallas, L., "Las verdades del borracho", en Hypnos XIV, 20, pp. 75-95, 2008.

Ferrari, G.R.F. y Griffith, T., Plato. The Republic, edition and translation, Cambridge, CUP, 2000.

Ferrari, G.R.F. (ed.), The Cambridge companion to Plato's Republic, Cambridge, CUP, 2007. http://dx.doi.org/10.1017/CCOL0521839637

Finlay, J., "The Night of Alcibiades", The Hudson Review XLVII, 1, pp. 57-79, 1994. http://dx.doi.org/10.2307/3852157

Gagarin, M., "Socrates 'hýbris' and Alcibiades Failure”, Phoenix XXXI, 1, pp. 22-37, 1977. http://dx.doi.org/10.2307/1087153

Gribble, D., Alcibiades and Athens. A study in literary presentation, Oxford, OUP, 1999.

Hunter, R., Plato’s Symposium, Oxford, OUP, 2004.

Juliá, V., Platón. Banquete, Introducción, traducción y notas, Buenos Aires, Losada, 2004. 
Kahn, Ch., "Plato's theory of desire", The review of metaphysics LXI, 1, pp. 77-103, 1987.

Larivée, A., "Eros Tyrannos: Alcibiades as the Model of the Tyrant in Book IX of the Republic", The Internationa Journal of the Platonic Tradition VI, pp. 1-26, 2012. http://dx.doi.org/10.1163/187254712X619575

Leroux, G., Platon. La République, Introduction, traduction et notes, Paris, Flammarion, 2004.

Mársico, C. y Divenosa, M., Platón. República, Buenos Aires, Losada. Introducción, traducción y notas, 2005.

Nichols, M.P., "Philosophy and Empire: On Socrates and Alcibiades in Plato's Symposium", Polity XXXIX, 4, pp. 502-521, 2007. http://dx.doi.org/10.1057/palgrave.polity.2300066

Palmer, M., "Alcibiades and the Question of Tyranny in Thucydides", Canadian Journal of Political Science XV, 1, pp.103-124, 1982. http://dx.doi.org/10.1017/S0008423900053087

Reeve, C.D.C., Plato.The Republic, Introduction and translation, Hackett.

Robin, L., Platon. Le Banquet, Paris, LBL, texte établi et traduit, 1951.

Rosen, S., Plato's Symposium, New Haven \& London, 1987.

Rowe, Ch., Plato. Symposium, Warminster, Aris \& Phillips Ltd, 1998.

Santas, G., The Blackwell guide to Plato's Republic, Oxford, Blackwell, 2006. http://dx.doi.org/10.1002/9780470776414

Seager, R., "Alcibiades and the Charge of Aiming at Tyranny", Historia: Zeitschrift für Alte Geschichte XVI, 1, pp. 6-18, 1967.

Vegetti, M., Platone. La Reppublica, Traduzione e commento, Bibliopolis, 1998.

Vickers, M., “Alcibiades on stage: Aristophanes' Birds”, Historia: Zeitschrift für Alte Geschichte XXXVIII, 3, pp. 267-299, 1989.

Vigo, A., "Autodistanciamiento y progreso moral. Reflexiones a partir de un motivo de la ética socrática”, Diadokbé V, 1-2, pp. 65-101, 2002.

Wohl, V., “The Eros of Alcibiades”, Classical Antiquity XVIII, 2, pp.349385, 1999. http://dx.doi.org/10.2307/25011105 